\title{
PEMILIHAN PAKAN ALAMI LARVA IKAN KAKAP MERAH, Lutjanus sebae
}

\author{
Regina Melianawati dan Philip Teguh Imanto
}

\begin{abstract}
ABSTRAK
Penelitian ini bertujuan untuk mengetahui pakan alami pilihan dari larva ikan kakap merah, Lutjanus sebae pada beberapa tingkat umur. Pemeliharaan larva dilakukan pada tangki polyPakan alami yang diberikan pada awal pemelihan yang dipertahankan pada intensitas 400 lux. dan copepodit, sedangkan naupli artemia dilakukan secara bertahap pada larva mulai diberikan pada larva umur 16 hari. Pengamatan menunjukkan bahwa jenis pakan alami berumur 4, 8, 12, 16, dan 20 hari. Hasil penelitian dan 8 hari adalah rotifera. Larva pada umur 12 harinan dipilih oleh larva, L. sebae pada umur 4 oleh larva. Larva pada umur 16 hari, nump 12 hari rotifera dan copepod dipilih secara berimbang merupakan jenis pakan alami yang dipilih copepod, copepodit copepod, dan naupli artemia 20 hari, naupli artemia merupakan pedangkan larva pada umur pakan alami tersebut tergantung pada tenis pakan alami yang dominan dipilih. Pemilihan jenis lambung dan kecepatan renang pada tingkat umur dan lebar mulut larva, kemampuan pencernaan ketersediaan pakan media pemeliharaan larva.
\end{abstract} \begin{abstract}
$\begin{array}{ll}\text { ABSTRACT: } & \text { Feeding preference on life feed of emperor snapper larvae Lutjanus sebae. } \\ & \text { By: Regina Melianawati and Philip Teguh Imanto }\end{array}$
This research was aimed to get the information about feeding preference on life feed of emperor snapper larvae at different ages. Larval rearing was done in $500 \mathrm{~L}$ polyethylene tank and artemia was given started at lay intensity. Feeding was rotifer and copepod at the beginning and The result showed that life feed rotifer Observation was done on larvae 4, 8, 12, 16, and 20 days old. 12 days old larvae the rotifer and copepod dominantly preferred by the 4 and 8 days old larvae, at larvae with nauplii copepod, copepodit copepod preferred in balance, and similar at 16 days old prefer dominantly on naupli artemia. Feeding , and naupli artemia. At 20 days old larvae were the age and mouth width of larvae, digestion preference on natural life feed was depending on ment pattern and the availability of eastion ability and swimming speed of larvae, also move-
\end{abstract} KEYWORDS:

emperor snapper, larvae, life feed, feeding preference

\section{PENDAHULUAN}

Kakap merah merupakan jenis ikan demersal. Umumnya ikan ini mendiami perairan berdasar keras (Nasution, 1993), namun jenis kakap merah muda sering dijumpai menempati perairan hutan bakau atau di daerah yang banyak ditumbuhi rumput laut (Anonim,
1992).

Usaha penangkapan ikan kakap merah menunjukkan peningkatan dari tahun ke tahun, sebagai akibat permintaan pasar (ekspor) yang cukup baik di pasaran dunia (Sugama \& Priono, 2003). Untuk membatasi kegiatan penangkapan yang berlebih maka usaha budi daya ikan kakap merah ini perlu dikembangkan. Penyediaan benih yang memadai merupakan salah satu permasalahan yang sangat mendesak untuk dicarikan pemecahannya (Imanto \&
Basyarie, 1993). Aspek penelitian biologi benih dari perkembangan embrio awal hingga mencapai benih pascalarva sangat penting artinya dalam menunjang teknologi produksi benih.

Di Balai Besar Riset Perikanan Budidaya Laut, Gondol, kegiatan penelitian mengenai biologi jenis ikan kakap merah, L. sebae baru dimulai pada tahun 2000. Penelitian mengenai perkembangan larva tingkat awal dan penyerapan nutrisi endogennya telah dilakukan (Imanto \& Melianawati, 2003).

Penelitian ini bertujuan untuk mengetahui tingkat pemilihan pakan (feeding preference) dari larva ikan kakap merah pada beberapa tingkatan umur dan pertumbuhan larva pada masing-masing tingkatan umur tersebut sebagai parameter pendukungnya. Pemilihan pakan alami yang dilakukan oleh larva merupakan satu parameter penting yang perlu 
diketahui karena hasil tersebut merupakan dasar atau pedoman dalam pemberian jenis pakan alami yang sesuai untuk larva. Hasil dari penelitian ini diharapkan dapat memberikan informasi dasar yang dapat diaplikasikan dalam usaha pembenihan jenis ikan tersebut.

\section{BAHAN DAN METODE}

Larva yang digunakan untuk pengamatan berasal dari hasil pemijahan secara alami induk ikan kakap merah yang dipelihara dalam tangki beton bervolume $100 \mathrm{~m}^{3}$ dengan sistem sirkulasi. Telur hasil pemijahan ditetaskan dalam tangki inkubator dan suhu penetasan diatur pada kisaran $28^{\circ} \mathrm{C}-29^{\circ} \mathrm{C}$. Larva yang menetas selanjutnya dipindahkan ke dalam tangki pemeliharaan larva yang terbuat dari polyethylene bervolume $500 \mathrm{~L}$. Pencahayaan pada tangki larva bersumber dari dua buah lampu TL 40 watt dan satu buah lampu halogen 100 watt. Pencahayaan buatan tersebut dipertahankan pada intensitas 400 lux selama 24 jam. Pemeliharaan dilaksanakan menggunakan sistem resirkulasi, di mana air yang mengalir keluar dari media pemeliharaan digunakan kembali setelah melalui penyaringan dengan tiga jenis filter sesuai dengan metode dari Billund Aquaculture (Steenfeldt et al., 2002). Media pemeliharaan dilengkapi pula dengan aerasi kecepatan lemah.

Pada saat larva telah membuka mulut dan memiliki pigmentasi mata yang sempurna yaitu hari kedua atau 35 hingga 50 jam setelah menetas, ke dalam media pemeliharaan diberikan Nannochloropsis ocullata.
Jenis pakan alami yang diberikan untuk pengamatan pada awal masa pemeliharaan larva adalah rotifera (Brachionus sp.) dengan kepadatan 10 ind. $/ \mathrm{mL}$ serta copepoda (Tisbe holuthuriae) stadia naupli dan copepoda dengan kepadatan 1 ind. $/ \mathrm{mL}$, sedangkan naupli artemia dengan kepadatan 2 ind. $/ \mathrm{mL}$ baru diberikan pada saat larva telah berumur 16 hari.

Pengamatan dilakukan secara bertahap pada larva yang berumur $4,8,12,16$, dan 20 hari. Pada masingmasing stadia umur tersebut diambil 5-10 ekor larva sebagai sampel, kemudian dilakukan pembedahan pada lambung larva tersebut. Pengamatan dikerjakan dengan menggunakan mikroskop stereoskopis. Pencatatan dilakukan terhadap jenis serta jumlah masing-masing jenis pakan alami yang ditemukan dalam lambung larva.

\section{HASIL DAN BAHASAN}

Hasil pengamatan terhadap pemilihan pakan alami oleh larva L. sebae dapat dilihat pada Gambar 1. Dari hasil tersebut terlihat adanya sifat memilih pakan yang dilakukan oleh larva $L$. sebae terhadap jenis pakan alami yang diberikan. Pada umur 4 dan 8 hari, larva hanya memilih dua jenis pakan alami dari tiga jenis yang diberikan yaitu rotifera dan naupli copepoda. Masing-masing dengan perbandingan $88,99 \%$ rotifera dan $11,01 \%$ naupli copepoda pada larva umur 4 hari, serta $92,92 \%$ rotifera dan $7,08 \%$ naupli copepoda pada larva umur 8 hari.

Ukuran.lebar mulut larva umur 4 hari tercatat sekitar 260 mikron dan memungkinkan untuk memangsa

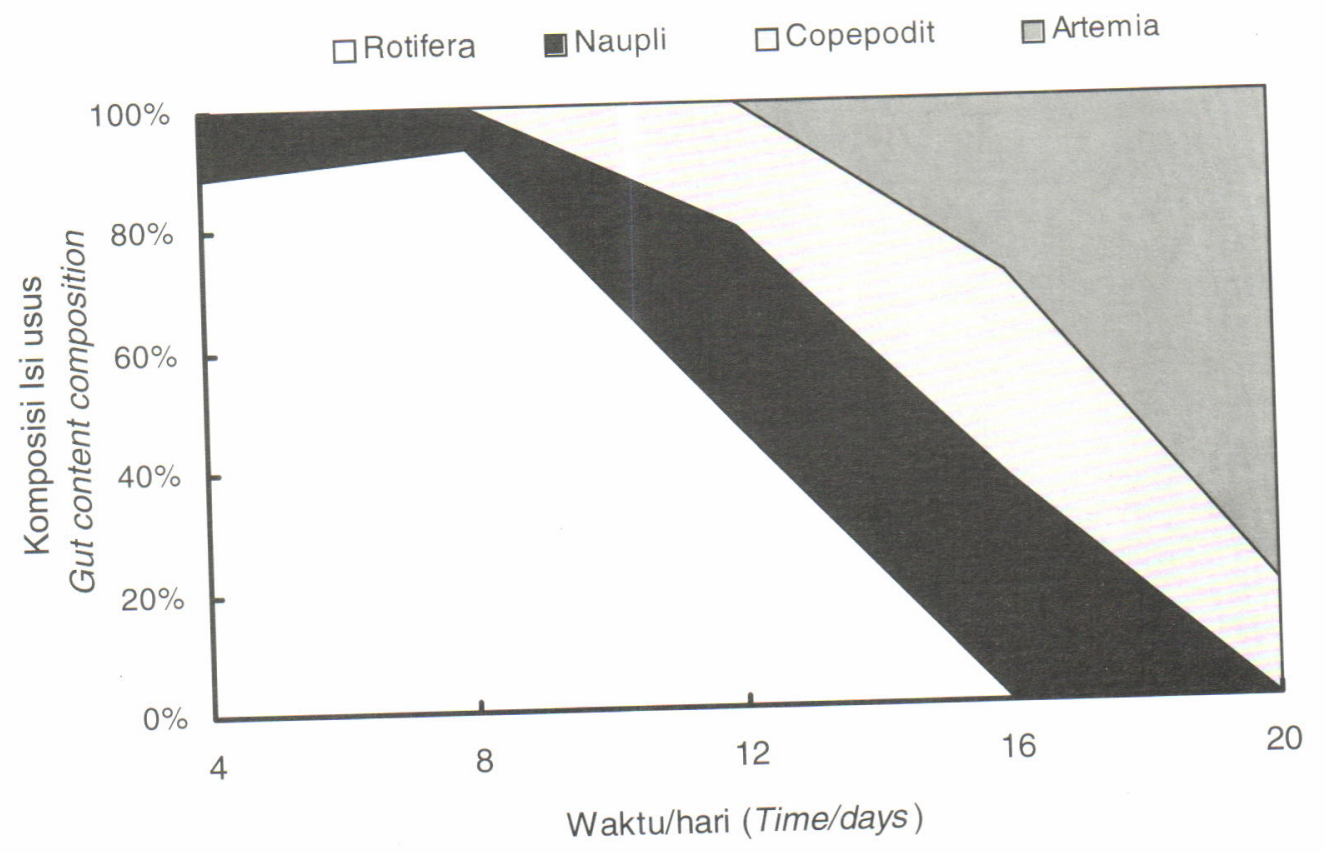

Gambar 1. Pemilihan pakan alami larva ikan kakap merah, L. sebae pada beberapa tingkatan umur Figure 1. Feeding preference on life feed of emperor snapper, $L$. sebae larvae under different ages 
semua jenis pakan yang diberikan, namun nampaknya larva cenderung untuk memilih pakan alami seperti yang tersebut di atas. Pemilihan terhadap kedua jenis pakan alami tersebut disebabkan karena ukuran keduanya relatif lebih kecil dibandingkan jenis pakan lainnya. Rotifera yang digunakan pada pengamatan ini berukuran antara 70-180 mikron dan naupli copepoda berukuran antara 60-80 mikron, sedangkan copepoda ukuran tubuhnya lebih besar yaitu 120 mikron ditambah dengan kaki-kaki yang cukup panjang seperti halnya hewan yang tergolong dalam klas krustase lainnya (Steenfeldt, 1997).

Pada kisaran umur $4-8$ hari, tingkat pemilihan pakan alami oleh larva di samping ditentukan oleh ukuran pakan alami, juga oleh ketersediaan pakan alami itu sendiri dalam media pemeliharaan. Ketersediaan rotifera yang lebih banyak dalam media pemeliharaan menyebabkan persentase pemilihan terhadap jenis pakan ini juga lebih tinggi. Pemilihan terhadap jenis pakan alami tersebut nampak proporsional dengan ketersedian masing-masing jenis tersebut dalam media pemeliharaan.

Sifat dari pakan alami itu sendiri diduga juga berpengaruh terhadap pemangsaan larva, di mana rotifera berenang pasif dalam gerakan spiral dan tersebar ke seluruh bagian media pemeliharaan sesuai dengan pergerakan massa air, sedangkan naupli copepoda cenderung berenang lebih aktif dengan gerakan terpatah-patah dan lebih sering berada pada lapisan permukaan. Kemampuan renang larva $L$. sebae sendiri pada umur tersebut belum sempurna karena masih terbatasnya kelengkapan morfologis larva itu sendiri, sehingga daya jelajah larva untuk berenang mencari mangsa juga relatif masih terbatas. Oleh karena itu, kesempatan larva untuk memangsa rotifera lebih besar disebabkan penyebaran pakan alami tersebut relatif lebih merata dibandingkan kesempatan larva untuk memangsa naupli copepoda yang lebih terbatas. Dengan kata lain, pada kisaran umur tersebut atau pada awal masa pemangsaan, larva cenderung hanya memangsa pakan alami yang berada didekatnya.

Copepoda stadia copepodit belum ditemukan dalam lambung larva pada umur $4-8$ hari. Hal ini diduga karena larva masih menemui kesulitan untuk memangsa copepodit yang memiliki kaki-kaki panjang dan kondisi lambung larva sendiri juga diduga belum mampu untuk mencerna copepodit yang bagian luar tubuhnya bersegmen dan cukup keras.

Larva umur 12 hari tercatat mulai memilin satu jenis pakan alami lagi selain rotifera dan naupli copepod yaitu copepodit. Perbandingan jumlah masingmasing jenis pakan tersebut yang ditemukan dalam lambung larva adalah 45,67\% rotifer; $33,67 \%$ naupli copepoda, dan 20,67\% copepodit. Dari hasil tersebut nampak bahwa rotifera masih mendominasi jenis pakan yang dipilih oleh larva. Hal ini juga menunjukkan bahwa pemberian rotifera harus dipertahankan dalam pemeliharaan larva $L$. sebae umur 12 hari. Mulai tumbuhnya sirip punggung dan sirip dada pada sebagian larva memungkinkan larva untuk lebih aktif berenang mencari mangsanya. Copepodit yang mulai bersifat benthic dengan kecenderungan berenang dan merayap pada dinding tangki pemeliharaan

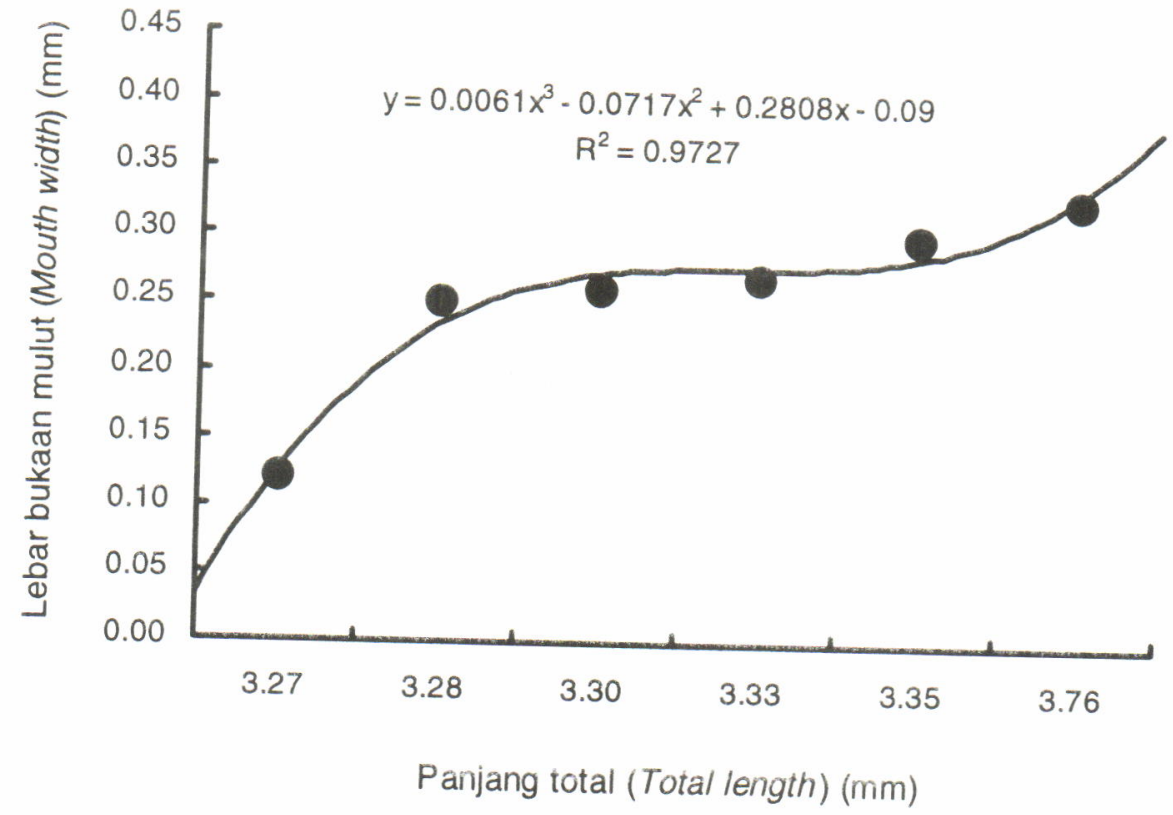

Gambar 2. Hubungan ukuran lebar mulut dengan panjang total larva ikan kakap merah, L. sebae

Figure 2. Relationship between mouth size and total length of emperor snapper larvae, L. sebae 
nampaknya merupakan mangsa yang mudah ditemukan serta ditangkap oleh larva yang pada umur tersebut lebar mulutnya rata-rata sudah di atas 500 mikron. Pada umur tersebut diduga kemampuan pencemaan larva juga sudah berkembang menjadi lebih sempuma sehingga mampu untuk mencerna copepodit.

Pada larva umur 16 hari, terlihat adanya perubahan jenis pakan alami yang dipilih oleh larva, di mana rotifer sudah tidak ditemukan lagi dalam lambung larva meskipun pakan tersebut tetap diberikan ke dalam media pemeliharaan. Sebaliknya larva mulai memilih naupli artemia sebagai salah satu pakan alaminya. Naupii artemia yang baru menetas ( $1-2$ jam) berukuran panjang 630 mikron dan lebarnya 186 mikron (Moretti et al., 1999). Naupli copepod masih ditemukan sebanyak $37,13 \%$; sedangkan copepodit tercatat sebanyak $33,97 \%$; dan nauplii artemia sebanyak 28,89\%. Berkaitan dengan kemampuan renang larva, pada umur ini larva sudah memiliki sirip dada dan sirip punggung yang masing-masing berukuran rata-rata $1,31 \mathrm{~mm}$ dan 1,12. $\mathrm{mm}$. Kelengkapan morfologis ini memungkinkan larva untuk berenang mencari mangsa dalam wilayah jelajah yang lebih luas dan mulai mampu menangkap mangsa yang sangat aktif bergerak seperti halnya naupli artemia.

Larva umur 20 hari terlihat hanya memilih dua jenis pakan alami saja yaitu copepodit dan artemia, masing. masing sebanyak $19,04 \%$ dan $80,96 \%$. Dari hasil tersebut terlihat bahwa hampir sebagian besar larva umur 20 hari cenderung memilih artemia sebagai pakannya.

Hasil tersebut menunjukkan adanya pergeseran jenis pakan alami yang dipilih oleh larva, yaitu perubahan dari yang berukuran kecil ke ukuran yang lebih besar. Pemilihan ini ternyata sesuai dengan perkembangan ukuran mulut dan volume lambung, kemampuan renang larva serta gerakan pakan alami (zooplankton) yang merangsang sifat pemangsaan itu sendiri. Perkembangan ukuran lebar mulut larva berkaitan erat dengan pertumbuhan larva itu sendiri (Gambar 2).

\section{KESIMPULAN}

* Jenis pakan alami yang dominan dipilih oleh larva ikan kakap merah, L. sebae umur 4 dan 8 hari adalah rotifer. Sedangkan pada umur 12 hari larva cenderung memilih rotifer dan copepod secara berimbang. Pada umur 16 hari larva memilih naupli copepod, copepodit copepod, dan naupli artemia secara relatif seimbang. Pada larva berumur 20 hari naupli artemia merupakan jenis pakan alami yang dominan dipilih oleh larva.

* Pemilihan jenis pakan alami oleh larva L. sebae berhubungan erat dengan perkembangan umur, ukuran mulut larva, kemampuan cema lambung. keaktifan berenang larva, sifat gerakan pakan alami, serta ketersediaan pakan alami itu sendiri dalam media pemeliharaan larva.

\section{SARAN}

Pada pemeliharaan larva kakap merah rotifer sebaiknya disediakan mulai awal pemangsaan hingga larva sekurang-kurangnya berumur 16 hari, naupli copepod disediakan pula mulai awal pemangsaan hingga larva sekurang-kurangnya berumur 20 hari, sedangkan untuk copepodit copepod dan naupli artemia mulai diberikan masing-masing pada larva umur 12 dan 16 hari.

\section{UCAPAN TERIMAKASIH}

Ucapan terima kasih disampaikan kepada Bapak Drs. Bejo Slamet, selaku tim pemeriksa makalah BBRPBL, Gondol yang telah memberikan koreksi terhadap tulisan ini, juga kepada Sdri. Restiana Wisnu Aryati dan Dwi Falida Hartanti yang telah membantu dalam penyiapan dan produksi pakan alami.

\section{DAFTAR PUSTAKA}

Anonim. 1992. Penelitian, penyebaran dan kelimpahan induk ikan (kakap, kerapu) untuk menunjang budidaya (domestika dan aquaculture). Sub Balitkanlut Semarang dalam Laporan Hasil Penelitian Sub Balitkanlut Semarang.

Imanto, P.T. dan A. Basyarie. 1993. Budidaya ikan laut, pengembangan dan permasalahannya. Prosiding Rapat Teknis Penelitian Perikanan Budidaya Pantai di Tanjung Pinang, No.10: 93-106.

Imanto, P.T. dan R. Melianawati. 2003. Perkembangan awal larva kakap merah L. sebae. Jurnal Penelitian Perikanan Indonesia edisi akuakultur, 9(1): $11-19$.

Moretti, A., M.P. Fernandez-Criado, G. Cittolin, and R. Guidastri. 1999. Manual on Hatchery Production of Seabass and Gilthead Seabream. Volume I. Rome. FAO, $194 \mathrm{pp}$.

Nasution, C. 1993. Kalipo, suatu rawai dasar untuk penangkapan ikan demersal di perairan berdasar keras. Prosiding Simposium Perikanan I. Badan Litbang Perikanan, Ispikani, Himapikani, JICA.

Steenfeldi, S.J. 1997. Production of the Live Feed Or. ganism Tisbe holuthuriae. Danish Institute for Fisheries Technology and Aquaculture, $25 \mathrm{pp}$.

Steenfeldt, S., P.B. Pedersen, A. Jokumsen, and I. Lund. 2002. Hatchery Production of Tropical Marine Fish in Recirculation Systems. Training course. Danish institute for Fisheries Research. Denmark, 103 pp.

Sugama, K. dan B. Priono. 2003. Pengembangan budidaya ikan kerapu di indonesia. Warta Penelitian Perikanan Indonesia edisi Akuakultur, 9(3): 20-22. 